\title{
Economic Feasibility of Agrivoltaic Systems in Food-Energy Nexus Context: Modelling and a Case Study in Niger
}

\author{
Srijana Neupane Bhandari ${ }^{1, *}$, Sabine Schlüter ${ }^{1}$, Wilhelm Kuckshinrichs ${ }^{2} \mathbb{D}$, Holger Schlör ${ }^{2}$, Rabani Adamou ${ }^{3}$ \\ and Ramchandra Bhandari ${ }^{1}$ (i)
}

1 Institute for Technology and Resources Management in the Tropics and Subtropics, TH Köln-University of Applied Sciences, Betzdorfer Strasse 2, 50679 Cologne, Germany; sabine.schlueter@th-koeln.de (S.S.); ramchandra.bhandari@th-koeln.de (R.B.)

2 Research Centre Jülich, Institute of Energy and Climate Research—Systems Analysis and Technology Evaluation (IEK-STE), 52425 Jülich, Germany; w.kuckshinrichs@fz-juelich.de (W.K.); h.schloer@fz-juelich.de (H.S.)

3 Faculty of Science and Techniques, Abdou Moumouni University of Niamey, Niamey BP 10662, Niger; rabadamou@wascal-ne.org

* Correspondence: srijana.neupane_bhandari@th-koeln.de; Tel.: +49-2218-2754-130

\section{check for} updates

Citation: Neupane Bhandari, S.; Schlüter, S.; Kuckshinrichs, W.; Schlör, H.; Adamou, R.; Bhandari, R. Economic Feasibility of Agrivoltaic Systems in Food-Energy Nexus Context: Modelling and a Case Study in Niger. Agronomy 2021, 11, 1906 https://doi.org/10.3390/ agronomy11101906

Academic Editor:

Miguel-Ángel Muñoz-García

Received: 26 June 2021

Accepted: 20 September 2021

Published: 23 September 2021

Publisher's Note: MDPI stays neutral with regard to jurisdictional claims in published maps and institutional affiliations.

Copyright: (c) 2021 by the authors. Licensee MDPI, Basel, Switzerland. This article is an open access article distributed under the terms and conditions of the Creative Commons Attribution (CC BY) license (https:// creativecommons.org/licenses/by/ $4.0 /)$.

\begin{abstract}
In the literature, many studies outline the advantages of agrivoltaic (APV) systems from different viewpoints: optimized land use, productivity gain in both the energy and water sector, economic benefits, etc. A holistic analysis of an APV system is needed to understand its full advantages. For this purpose, a case study farm size of 0.15 ha has been chosen as a reference farm at a village in Niger, West Africa. Altogether four farming cases are considered. They are traditional rain-fed, irrigated with diesel-powered pumps, irrigated with solar pumps, and the APV system. The APV system is further analyzed under two scenarios: benefits to investors and combined benefits to investors and farmers. An economic feasibility analysis model is developed. Different economic indicators are used to present the results: gross margin, farm profit, benefit-cost ratio, and net present value (NPV). All the economic indicators obtained for the solar-powered irrigation system were positive, whereas all those for the diesel-powered system were negative. Additionally, the diesel system will emit annually about $4005 \mathrm{~kg} \mathrm{CO}_{2}$ to irrigate the chosen reference farm. The land equivalent ratio (LER) was obtained at 1.33 and 1.13 for two cases of shading-induced yield loss excluded and included, respectively.
\end{abstract}

Keywords: agrivoltaic; food-energy nexus; solar-powered irrigation; benefit-cost ratio; land equivalent ratio

\section{Introduction}

Food and energy are two of the main needs for human wellbeing. Demand for both these resources is increasing globally, while it is expected to increase significantly in developing countries in the future. The situation is severe in countries in the Sahel region of Africa. Food security is an important issue there. Under extreme weather conditions, i.e., drought, food production can be secured and increased with energy-intensive methods, such as pressurized irrigation. Niger is one of such countries where energy and food security issues are predominant. The country has a high solar energy potential, which so far is little exploited. There are many challenges to provide enough food and energy for a growing population in the country. This will be further complicated due to predicted climate change impacts in the agricultural sector.

The use of an agrivoltaic (APV) approach could be an important contribution to overcome some of these challenges. Solar energy can produce electricity, which is needed for various process steps of farming (e.g., water pumping for irrigation, postharvest cold storage, etc.). According to the Fraunhofer Institute of Solar Energy Systems (ISE) [1], "the APV is a system technology that enables the simultaneous main agricultural production 
and secondary solar power generation on the same area and which seeks to optimally use the synergy effects and potentials of both production systems". This concept dates back to 1981 at Fraunhofer ISE in Freiburg [2]. There are concerns that the shadow of the solar system may hinder plant growth. To avoid these problems, the right choice of crops is necessary. For this purpose, the country's relevant food crops must be categorized with respect to shade tolerance. After this, an appropriate system configuration needs to be chosen, e.g., one of the following three [3]: (i) on the ground: crops (cereals, vegetables, fruits, etc.); (ii) above the crops: solar panels mounted on pillars; and (iii) process: Solar panels will get a part of the sunlight and leave the remaining light for the crop's growth.

The main objective of this study is to carry out an economic feasibility study of an APV system at a selected site in Niger (Dar Es Salam village in the Dosso region) and to present the quantitative results for different economic indicators. To compare the results, a reference farm size is used and different farming practices are analyzed: with rain-fed irrigation and diesel/solar only/APV powered irrigation. At the same time, socio-technical aspects (social-behavioral, rural development) are considered to interpret the economic results so that the stakeholders can make an investment or land use decision in a holistic way.

The study has some limitations too. It has been based on theoretical assumption, without having any experimental APV or irrigation system on the chosen site. For economic and farming calculations, multiple assumptions are made for the input parameters, both at cost and revenue sides. Many such data are based on farmer's experiences at the site, collected during the field survey. The results need to be verified with field experiments first before multiple such projects are implemented in similar villages.

Although the comparison of different farming systems might be seen by some experts as incompatible, the ultimate benefit of such APV projects should be seen as multi-sectoral. Such benefits (profits) should not be viewed only in the energy sector (investors or operators). The results of this study could be useful to support the decision-making of the farming communities on whether or not to take part in such APV projects.

This paper has been organized as follows. The next section describes the case study frame, with a brief literature review on APV systems and the country profile of Niger. The following sections present the methods used for feasibility analysis and the model. Afterward, results, discussions, and conclusions are presented.

\section{Study Frame}

\subsection{Agrivoltaic (APV) Systems}

As mentioned earlier, APV allows the simultaneous harvest of agriculture products and solar electricity on the same farm area by optimizing both production systems [1]. Brohm and Khanh [3] defined APV as the dual use of the same land area for solar electricity and agricultural production, including aquaculture. Others define APV as an emerging approach of harvesting energy and food together in a given land area to maximize land productivity with additional benefits including improved crop yield and socio-economic welfare of farmers [4-6]. Hernandez and colleagues confirmed that APV allows both agricultural production (food or energy crops) and solar energy generation within the same land area [7]. There are other similar definitions of APV systems in the publications from many other authors [8-13], etc. In a broader sense, all these definitions are similar, as they refer to the dual use of the same land area at the same time. Also, there are different terminologies evolved to describe this approach over the period. These include solar dual-use, agro-photovoltaics, agri-photovoltaics, agrivoltaic, etc. This term agrivoltaic (and in short APV) is used in this paper to represent this concept.

Several studies have already analyzed the performance of APV systems. Different aspects such as crop types, APV system configuration, irrigation water, etc. are common discussion points in most of these studies [14]. Vyas [15] discussed several advantages of the APV systems. Among others, the author highlighted the positive effects of shade beneath the solar modules on fresh salads and vegetables in desert climates. Sekiyama and Nagashima [13] aimed to identify the right solar photovoltaic (PV) system that could 
ease the stress between food and energy production in the same land area. They presented results by taking a case of an APV system in the cornfield. Santra et al. [16] integrated the rainwater harvesting channels with solar modules in their APV system. The collected water was used for module cleaning as well as for supplemental irrigation. Dupraz et al. [10] published a study in France comparing the results of separated energy and agri production vs. combined one. A comparison of land use for solar electricity (for electric mobility) vs. biofuel (as vehicle fuel) was also made.

Weselek et al. [6] carried out a systematic review to analyze the applications, challenges, and opportunities of APV systems. This was one of the most extensive reviews done in the field including results from a wide range of projects in many countries. The authors also summarized the effects of shading on different crops reported by several pieces of literature.

Some other findings on productivity and benefits were: the crops' growth rates underneath the PV modules were less, land productivity can increase by up to $70 \%$ when energy and crops are planted in the same field and APV systems enhance the farmer's economic benefits [9]. Dual benefits to the farmers are also reported at grape farms in India by Malu et al. [17]. Valle et al. [18] analyzed the effect of fixed type vs. tracking type PV systems on energy and lettuce production. An interesting finding was that tracked systems had not only increased electricity production, but also helped crop biomass growth due to slightly higher transmitted radiation to the crops (compared to the fixed types).

Further studies reported the land productivity increase with the dual use of crop and PV on the same land. These effects are expected further positive in semi-arid or arid areas. One of the reasons is the decreased water loss from the topsoil [19]. Decreased soil evaporation reduces the loss in agri-production [20]. Furthermore, the shade of PV modules during high solar irradiance hours could be beneficial for selected crops planted in these regions [21]. When it comes to the height of APV mounting structures, different heights are used depending upon the need for machinery used for farming underneath the PV modules. Varying examples of height for specific real or hypothetical projects are reported in the literature, e.g., $3 \mathrm{~m}$ in Japan [22] or $5 \mathrm{~m}$ in Spain [23].

APV's joint benefits for electrification and irrigation are presented by lbrik [24]. By taking the arid region case at two rural communities in Palestine, the author analyzed how the diesel (as a fuel) dependency could be minimized by using such APV systems as extended solar microgrids. Pascaris et al. [25] analyzed the benefits and challenges that farmers perceive with the use of APV systems. Unlike the mainstream studies on APV, which are mostly project or pilot plant-based analyses, this study highlighted the generic barriers in the agriculture sector. The authors suggested the relevant stakeholders address these barriers for the successful and widespread implementation of APV systems. Moreda et al. [23] analyzed the profitability of a hypothetical APV system deployed on irrigated arable lands of southwestern Spain. The authors used the internal rate of return (IRR) as an economic indicator to check the profitability for different scenarios of crop types and solar modules orientation (south vs. southeast). Calculated IRR values were between $3.8 \%$ and $5.6 \%$.

In terms of productivity, APV's benefits include crops protection from radiation stress, lower water demand due to reduced evaporation, higher crop yields in case of shadetolerant crops, etc. [26]. This can contribute to enhancing economic development and food security specifically in rural areas, offering promising options for food production, water savings, and renewable energy production at the same time and location [27]. They can provide access to electricity, where this is not the case previously [7]. It helps to create new jobs in the farming and energy sector and to improve the socio-economic standard of living for people, especially farmers [28]. Generating solar electricity supports $\mathrm{CO}_{2}$ emission reduction, thus it helps to meet the national climate change targets [3]. Water can be harvested and controlled for crop irrigation and other purposes by systematically using the APV infrastructure: PV arrays can act as irrigation run-off channels, which can drain the water directly on the crops [5]. The water used for cleaning the dust on solar 
panels can be used for irrigation of vegetation cultivated under the panels [29]. Having vegetation underneath and around solar panels can reduce the levels of dust and soiling on the panels [30].

Although the APV has significant advantages, there are some challenges too. There is a need for a more comprehensive understanding of technical and economic aspects together with the agricultural issues. Furthermore, factors affecting societal acceptance of these new applications need to be studied. From the project implementation perspective, APV systems are challenging because they strongly interact with agriculture, the local economy, and the stakeholders on-site [31]. The APV systems are costlier than groundmounted PV systems. At the policy level, the issue of PV electricity sales to local consumers, integration to the grid, etc. are not addressed in many countries yet, unlike for PV-only solar power systems. Further, there could be practical obstacles (and additional costs) on the farming side. As these systems are relatively new, studies on more such projects at different scales (smallholder to utility-scale) are needed before answers can be found for these open questions.

The choice of suitable crops for APV applications is crucial, but it is also a challenge to assess in the African context without any best practice pilot projects available. As reported in different literature, most assessments on shading-tolerance and dual-use suitability have been made in Germany, France, Italy, China, and the USA. These projects give only an indication for their application in the context of Niger, because the climate is different except in part of the USA (Arizona). A fundamental effect of the shading caused by the PV modules is reduced water evaporation from the soil. Obviously, this has a positive effect, particularly in water-scarce arid regions, but it hinders the photosynthesis process. The following categorization (Figure 1) of suitable crops for APV has been derived by compiling the literature information.

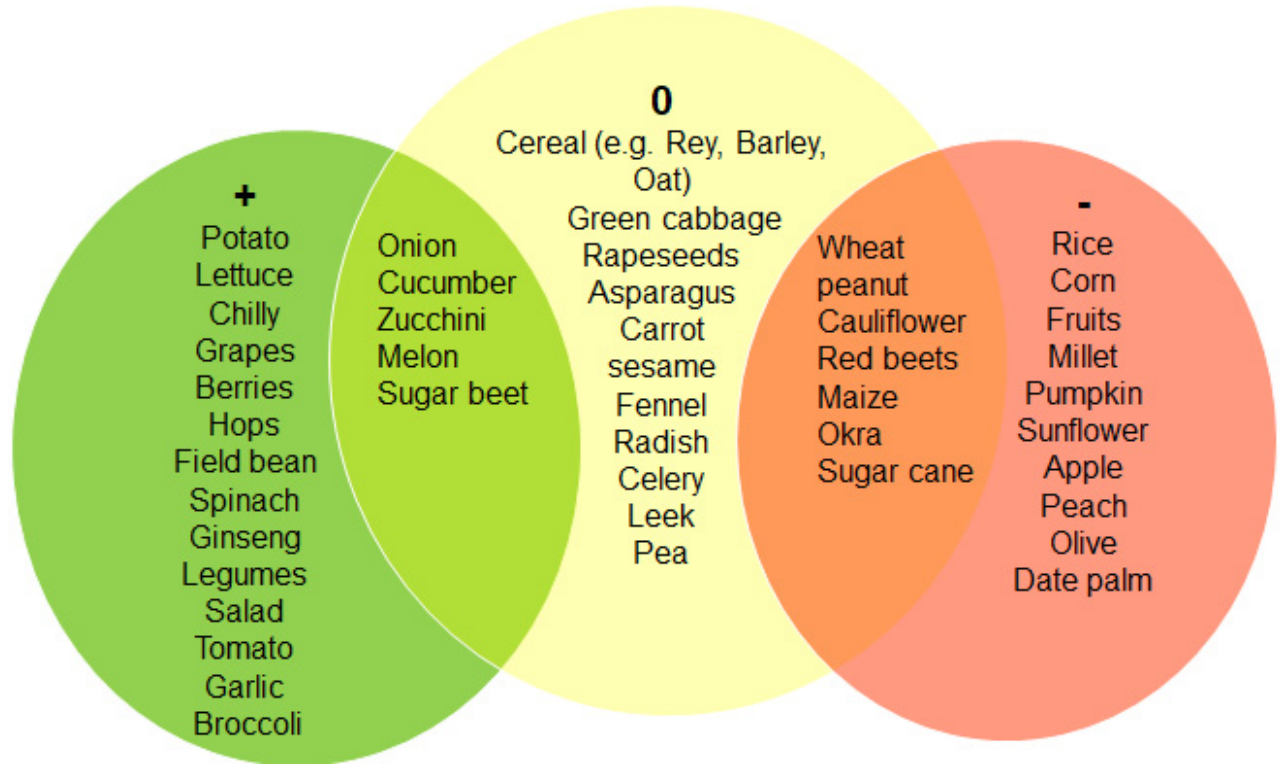

Figure 1. Suitable crops for solar dual-use (compiled from $[1,3,10])$.

Crops that perform better with shading are put under the " + " category (green), whereas the shade-intolerant crops are under "-" (red). The crops under the " 0 " category are indifferent to shade when the overall crop yield is considered. Although this categorization gives a first overview of crops selection, it might not apply to all the locations around the globe. Field experiments are necessary to verify this. 


\subsection{Niger-Country Profile}

Niger is a landlocked country located in West Africa in the Sahel Zone. The country's terrain has predominately desert plains and sand dunes. The country is exposed to a mostly hot and dry desert climate with frequent sand storms. Niger is prone to natural hazards, mainly recurring droughts [32]. According to 2011 data, out of the country's surface area of about 1.27 million $\mathrm{km}^{2}$, about $35.1 \%$ of the land was used for agriculture $(12.3 \%$ arable land, $22.7 \%$ pasture, and $0.1 \%$ permanent crops). Forest covers only $1 \%$ of the total land. The remaining $63.9 \%$ is desert and built environment. In 2012, irrigation was available to only about $1000 \mathrm{~km}^{2}$ farmland [32].

According to 2019 estimates, the country has about 23 million population [33]. An estimated $17 \%$ of people live in urban areas, while the remaining majority live in rural areas. The country's average annual population growth rate at $3.66 \%$ is one of the highest in the world [32].

In 2017, about $65.2 \%$ of the country's population had access to safe drinking water. This share was high in urban areas at $95.7 \%$ and low in rural areas at $59.2 \%$. The remaining $34.8 \%$ of people were exposed to unimproved drinking water with about $4.3 \%$ in urban areas and $40.8 \%$ in rural areas [32]. The available total annual water resource (surface water and groundwater) of Niger was reported at about 34.05 billion $\mathrm{m}^{3}$ in 2017, out of which, only 1.751 billion $\mathrm{m}^{3}$ was total annual consumption in the same year [34]. Therefore, it is possible that groundwater could be extracted for irrigation in the country by implementing APVs.

Due to large family sizes, the farming land is divided into smaller plots. Children inherit it from their parents. Over the generations, plots sizes are reduced. These small landholdings limit mechanization and thereby hinder food production growth. Common agricultural products grown in the country are cowpea, cotton, peanut, millet, sorghum, cassava, and rice. The subsistence-based agricultural economy is frequently disrupted by droughts, which are common to the Sahel region of Africa. The monthly average precipitation for the capital city of Niamey is given in Figure 2. The rainy season is also the main agricultural season in the country. These climate extremes have a direct impact on the livelihood of local people, including the food and water supply.

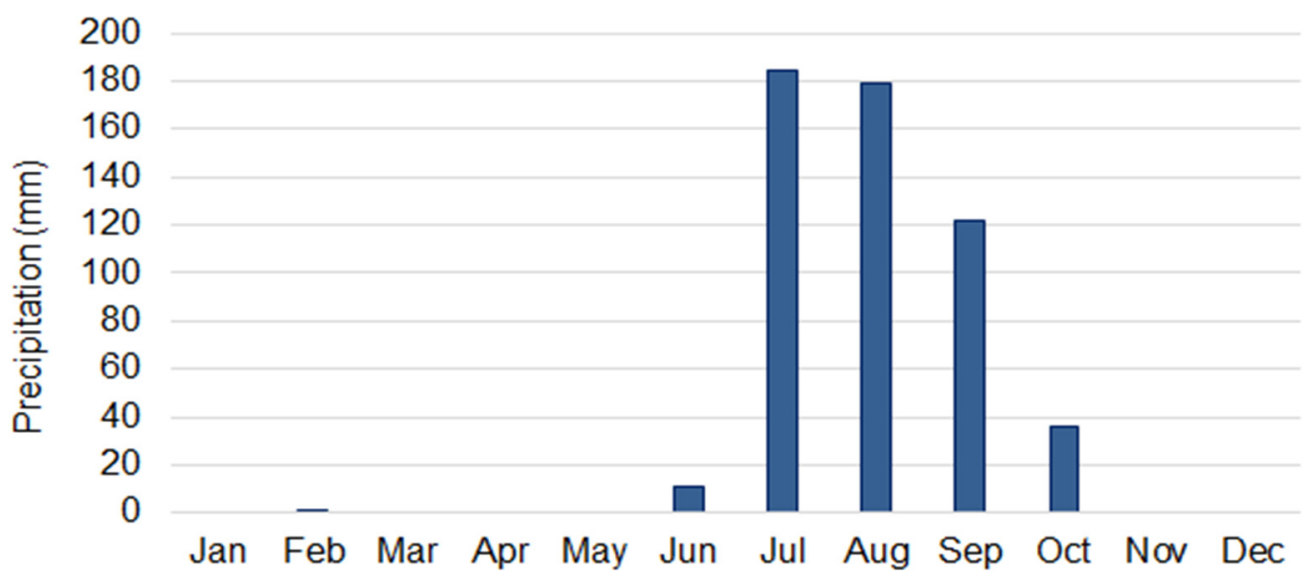

Figure 2. Monthly average precipitation in Niamey (data from [35]).

Due to its geographical location and hot-arid climate, there are not enough rivers or rivulets to divert water for agriculture. River Niger is the only available river in the country, even this river can be dry in some sections in the dry season (e.g., May). Solar electricity-driven groundwater pumping systems could be more reliable irrigation options.

More than $80 \%$ of the country's population is dependent on agriculture. Agri sector contributes to over $40 \%$ of the gross domestic product (GDP). Productivity of the agricultural sector is relatively low. A country's agriculture relies heavily on climatic conditions. When rainfall is less, the country suffers from additional food shortages. Even in normal 
rain conditions, the country relies on imports to meet national food demand [35]. The Sahel Sahara zone (north of Niger) is popular with livestock farming due to available land for pasture. Rain-fed crops and crop-livestock farming systems dominate the southern belt. The main crops there are dryland cereals (millets and sorghum) and legumes like cowpea and peanut. Millet is the main staple crop in Niger covering $65 \%$ of the cultivated land. The most productive (and irrigated) land is located along the Niger River [35], where another important cereal, rice, is produced.

Availability of more irrigation water would increase agricultural production. Solarpowered water pumps could be one of the solutions to support Niger's agricultural sector. However, business models and financing options are not yet established to offer this solution on a commercial scale [36].

Besides the cereals mentioned above, people in the areas close to the Niger River also produce many vegetables as cash crops. The study [37], in the suburb of Niamey, identified the production of many vegetables and their frequency of farming shown in Figure 3 . This information, together with the field survey at the case study site, has been used to select the top five cash crops for the economic analysis in this study.

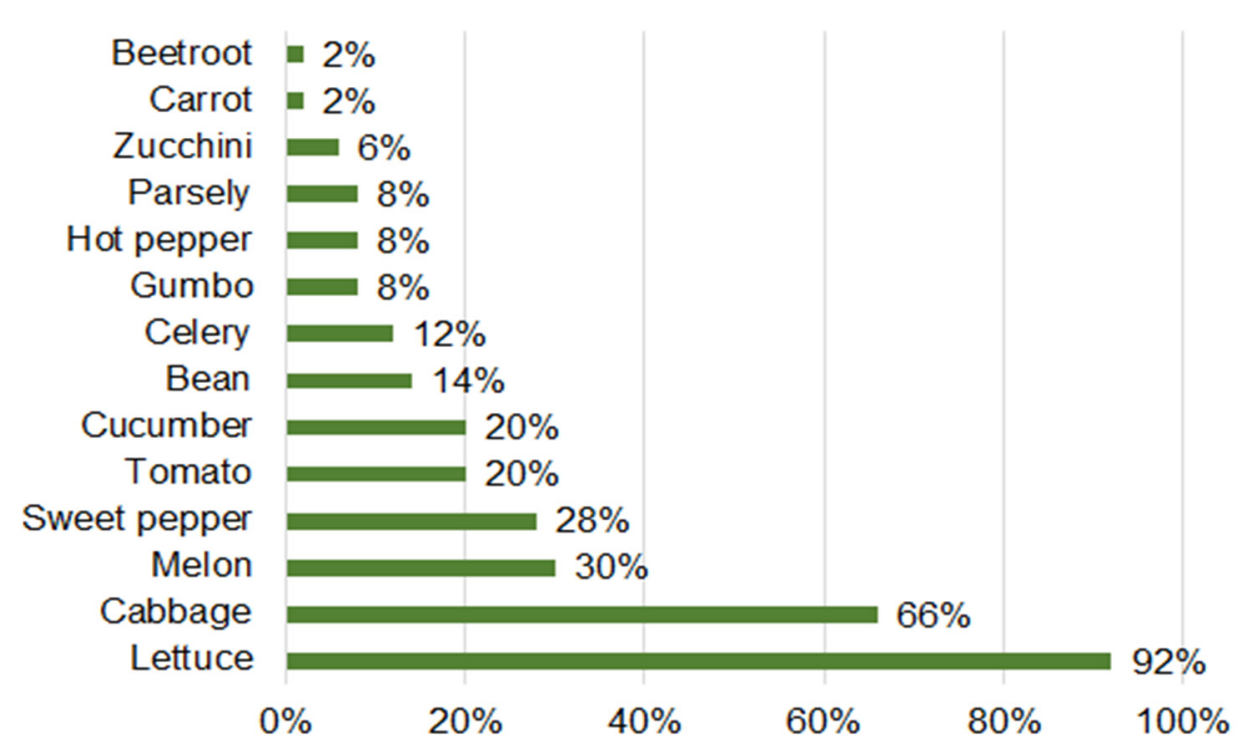

Figure 3. An example of different crops production in the suburb of Niamey (Data from [37]).

The national electrification rate is quite low, almost three out of four people do not have access to electricity [38]. The situation in rural areas is worse [39]. Currently, more than half of Niger's electricity supply is imported from Nigeria [40]. Even in areas with access to electricity, including the capital city Niamey, the supply is not reliable.

Indeed, off-grid solar systems could meet the energy demand in rural areas. Solar power could be combined with water pumping to meet the water demand for drinking and irrigation purposes. This approach of combining solar energy use with food production and water supply can be addressed by using the APV system, the focus of this study.

\section{Materials and Methods}

This section has been divided into two parts: first, the data collection steps are described followed by economic indicators and assumptions under considered scenarios.

\subsection{Data Collection}

Data collection was carried out by literature analysis combined with a field survey with a set of structured questionnaires. One part of the survey questionnaire was intended for local farmers, while the other part was for experts. Local university members in Niamey distributed the questionnaires among the target stakeholders in Niger (village farmers, 
academics, and students). A reference farming village was selected in Dar Es Salam in the Dosso Region of the country (about $75 \mathrm{~km}$ Southeast of Niamey). The survey was conducted in October 2020 and 124 households were visited.

At the farming side, the data include local common crop types, cropping seasons, land preparation practices, reference harvest quantity in reference farm size, agro-processing activities, postharvest management, local market for the products (or self-consumption), market price both for selling and purchasing of agri-products, costs for farming activities, etc. On the solar PV side, data include the cost of the solar plant (capital cost for installation, operation), electricity production, and selling prices (surplus selling and self-consumption). The climate data (solar radiation, precipitation, temperature, etc.) were taken from a meteorological/satellite database (Meteonorm V.8).

To analyze the data in line with the paper's objectives, a model was developed to evaluate the economic feasibility of a reference size project for both solar plant operators and farmers.

\subsection{Crop Yield and Energy Production Combined}

To increase land-use efficiency, energy and food production can be combined on the same land area. This can be measured by using the concept of land equivalent ratio (LER) [3]. The LER of an APV system can be defined as in Equation (1):

$$
L E R=\left(\frac{\text { Crop yield in dual use }}{\text { Mono crop yield }}\right)+\left(\frac{\text { Electricity yield in dual use }}{P V \text { electricity yield }}\right)
$$

If LER is $>1$, APV system is more effective than producing only crop or only energy. Mixed cropping systems have usually LERs between 1.0 and 1.3 [10].

\subsection{Indicators for Farming Side}

The indicators used in economic modeling for the farming side are described below in Section 3.3, which are adapted from [41].

\subsubsection{Gross Margin}

The gross margin of farming is obtained by subtracting the variable costs from the value of production (i.e., revenue) by using Equation (2).

$$
\text { Gross margin }=\text { Value of production }- \text { Variable costs }
$$

Value of production is calculated by multiplying the produced quantity and price. Cost of production refers to the expenses involved in the production of crops. It is divided into two: variable and fixed costs. Fixed costs remain constant as production changes. These costs include the costs of farm equipment and water pumps/irrigation systems. Smallholder farmers have very small fixed costs, e.g., the cost for small agri-tools. Land purchase or leasing costs would also fall under this category, but such costs are not considered in the analysis, assuming farmers own the land. Variable costs vary when the production changes as this leads to a change in the amount of inputs used (and also the yield harvested).

\subsubsection{Farm Profit}

Farm profit is the money left after variable and fixed costs are paid back from the value of production as shown in Equation (3). This is an important indicator for farmers.

$$
\text { Farm profit }=\text { Value of production }- \text { Total costs }(\text { fixed }+ \text { variable })
$$




\subsubsection{Benefit-Cost Ratio (B/C Ratio)}

Benefit cost ratio is calculated by dividing the total income by total cost, as shown in Equation (4).

$$
\text { Benef it cost ratio }=\frac{\text { Value of production }}{\text { Total cost }}
$$

\subsection{Economic Indicators for APV Side}

For the APV side, further indicators are needed for the economic analysis because the cash flows occur over several years, and discounted cash flow analysis is necessary. The electricity generated from the PV system needs to be calculated by considering solar radiation data on-site and other parameters that affect the electricity yield (such as degradation rate).

Net present value is calculated by using Equation (5).

$$
N P V=\sum_{n=0}^{N} \frac{R_{n}-C_{n}}{(1+d)^{n}}
$$

where,

- d Discount rate (\%)

- NPV Net present value $(€)$

- $\mathrm{R}$ Revenue $(€)$

- C Costs $(€)$

- $n \quad$ Numbers of years (0..to...N)

The present value of the total $\operatorname{cost}\left(\mathrm{C}_{\mathrm{pv}}\right)$ can be calculated by using Equation (6).

$$
C p v=C_{I, n=0}+\sum_{n=0}^{N} \frac{C_{O M}}{(1+d)^{n}}
$$

where,

- $\mathrm{C}_{\mathrm{I}}$ Total initial costs for PV and APV structure in year $0(€)$

- $\mathrm{C}_{\mathrm{OM}}$ Annual operation and maintenance $(\mathrm{OM}) \operatorname{cost}(€)$

- N Project lifetime, years

The annual energy yield from the PV system $\left(E_{n}\right)$ can be calculated using Equation (7).

$$
E_{n}=P_{\text {peak }} Q \frac{G}{I_{S T C}}\left(1-d_{g}\right)^{n}
$$

where,

- $\mathrm{d}_{\mathrm{g}}$ Energy yield degradation rate $(0.5 \%$ per year)

- $\quad P_{\text {peak }}$ Installed solar capacity at APV plant (50 kW)

- Q Performance ratio (value of only $60 \%$ is considered, decentralized grid)

- $\quad$ ISTC $_{\text {STC }}$ Constant value (solar irradiance at standard test condition, i.e., $1 \mathrm{~kW} / \mathrm{m}^{2}$ )

- G Solar radiation falling on solar panels at the project site $\left(\mathrm{kWh} / \mathrm{m}^{2}\right.$.year

Total electricity generated in all years $\left(\mathrm{E}_{\text {total }}\right)$ can be calculated by using Equation (8):

$$
E_{\text {total }}=\sum_{n=1}^{N} E_{n}
$$

The levelized cost of energy (LCOE) of a solar PV plant is the ratio between the total costs of the plant $(€)$ and total electricity production $(\mathrm{kWh})$, both over the economic lifetime 
of the project, as shown in Equation (9). It allows comparison of cost of electricity from different sources.

$$
L C O E=\frac{C_{P V}}{\sum_{n=0}^{N} \frac{E_{n}}{(1+d)^{n}}}
$$

The levelized cost of water (LCOW) can be also calculated in a similar manner, by dividing the present value of water pumping costs with total irrigation water demand throughout the project's economic lifetime.

\subsection{Diesel Pumping System}

With the help of literature, a pump size needed for the irrigation of reference farm size ( 0.15 ha land area) is calculated. The pumping system power requirement can be obtained by using a simplified Equation (10) [42]:

$$
P=\rho g Q T_{d h} \eta
$$

where,

- $\quad$ P Hydraulic power required for pumping (W)

- $\rho$ Density of water $\left(1000 \mathrm{~kg} / \mathrm{m}^{3}\right)$

- $g$ Acceleration due to gravity $\left(9.81 \mathrm{~m} / \mathrm{s}^{2}\right)$

- Q Flow rate of the pump $\left(0.001 \mathrm{~m}^{3} / \mathrm{s}\right.$, assumed to be operated for about $3 \mathrm{~h}$ a day, available water for irrigation in a day will be about $7.2 \mathrm{~L} / \mathrm{m}^{2}$ )

- $\quad \mathrm{T}_{\mathrm{dh}}$ Total dynamic head (m)

- $\eta$ Efficiency of the pump

Considering the pumping height about $70 \mathrm{~m}$ and the pumping efficiency of $60 \%$, the pumping power required (for 0.15 ha farming area) has been calculated at $1.15 \mathrm{~kW}$.

The chosen pump size is $1.5 \mathrm{~kW}$ to match the next available market size. To operate this pump, about $2 \mathrm{~L}$ diesel is needed in one hour. Considering no or less irrigation water requirement during rainy days, between crop harvest and new seeding, etc., the pump will be operated only about 250 days in a year. Considering that the water will be pumped out from the existing well, no drilling costs are considered even if sometimes the drilling costs can be very high in a new location where the groundwater level is very low. The same assumption will be considered for the case of the solar power irrigation system, so that the results are comparable.

\subsection{Field Survey and Cases under Analysis}

The field survey confirmed that the case study village of Dar Es Salam has significant problems with water and energy supply. This has a direct impact also on agriculture and livestock production. Thus, one of the important issues, the irrigation water supply, have been analyzed to compare the farm production without and with irrigation systems. Two irrigation techniques-diesel and solar energy driven pumps have been considered for comparison.

Altogether four cases are considered. The first three are to analyze the benefits to farmers. The last one is to analyze benefits to PV investors as well as combined benefits to farmers and investors.

\subsubsection{Case 1: Traditional Farming, Rain Fed Irrigation}

In this case, the business as usual farming practice has been considered. Farmers grow their crops only during the rainy season. They continue farming the usual major cereals, i.e., millet and sorghum. They grow cowpea as intercrop and partly also peanut. Considering the total cost of farming and the total value of production of those produces, economic indicators are calculated and the results are presented. The assumptions considered for the economic analysis of this case are shown in Table 1. 
Table 1. Basic assumptions for cases 1-3 (traditional farming, diesel, and solar PV).

\begin{tabular}{|c|c|c|c|}
\hline Parameters & Case 1, Traditional & $\begin{array}{l}\text { Case 2, Diesel Powered } \\
\text { Irrigation }\end{array}$ & Case 3, Solar PV Irrigation \\
\hline Land area & 0.15 ha & 0.15 ha & 0.15 ha \\
\hline Irrigation type & Rainfed & $\begin{array}{l}\text { Diesel pumps for } \\
\text { groundwater pumping from } \\
\text { the well }\end{array}$ & $\begin{array}{l}\text { Solar PV powered pumps for } \\
\text { groundwater pumping from } \\
\text { the well }\end{array}$ \\
\hline Farming method & $\begin{array}{l}\text { Traditional, human labor and } \\
\text { animals use, } 1 \text { crop cycle per year }\end{array}$ & $\begin{array}{l}\text { Cash crops (green vegetables), } \\
4 \text { crop cycles per year }\end{array}$ & $\begin{array}{l}\text { Cash crops (green vegetables), } \\
4 \text { crop cycles per year }\end{array}$ \\
\hline Main produces considered & $\begin{array}{l}\text { Sorghum, millet, cowpea, } \\
\text { and peanut }\end{array}$ & $\begin{array}{l}\text { Salad, cabbage, tomato, mint, } \\
\text { and okra }\end{array}$ & $\begin{array}{l}\text { Salad, cabbage, tomato, mint, } \\
\text { and okra }\end{array}$ \\
\hline $\begin{array}{l}\text { Other items not } \\
\text { considered in revenue }\end{array}$ & - & $\begin{array}{l}\text { Possible electricity generation } \\
\text { and sale using the same diesel } \\
\text { engine. Theoretically, it will } \\
\text { be possible to schedule water } \\
\text { pumping during the daytime } \\
\text { and electricity generation in } \\
\text { the evening. }\end{array}$ & - \\
\hline Cost parameters & $\begin{array}{l}\text { Farming land preparation, seeds, } \\
\text { planting, fertilizers, harvest, etc. }\end{array}$ & $\begin{array}{l}\text { Farming land preparation, } \\
\text { seeds, planting, fertilizers, } \\
\text { harvest, etc. } \\
\text { Additionally, investment for } \\
\text { diesel pump (depreciation of } \\
\text { the first year), operating costs } \\
\text { due to diesel consumption } \\
\text { per year. }\end{array}$ & $\begin{array}{l}\text { Farming land preparation, } \\
\text { seeds, planting, fertilizers, } \\
\text { harvest, etc. } \\
\text { Additionally, investment for } \\
\text { solar pump (depreciation of } \\
\text { the first year), a small } \\
\text { operating/maintenance } \\
\text { (O/M) costs per year. }\end{array}$ \\
\hline $\begin{array}{l}\text { Cooperative or } \\
\text { community loan share }\end{array}$ & $50 \%$ of total cost & $50 \%$ of the total cost & $50 \%$ of the total cost \\
\hline Loan interest rate & $10 \%$ for a period of 8 months & $10 \%$ for a period of 8 months & $10 \%$ for a period of 8 months \\
\hline Revenue & $\begin{array}{l}\text { Self-consumption (market value } \\
\text { set as pseudo selling price) }\end{array}$ & $\begin{array}{l}\text { Selling the harvested cash } \\
\text { crops to the market (e.g., in } \\
\text { Kodo) or sales to local traders } \\
\text { who re-sale the produce to the } \\
\text { city of Niamey }\end{array}$ & $\begin{array}{l}\text { Selling the harvested cash } \\
\text { crops to the market (e.g., in } \\
\text { Kodo) or sales to local traders } \\
\text { who re-sale the produce to the } \\
\text { city of Niamey }\end{array}$ \\
\hline Target economic indicator & $\begin{array}{l}\text { Gross margin, farm profit, and } \\
\text { B/C ratio }\end{array}$ & $\begin{array}{l}\text { Gross margin, farm profit, and } \\
\mathrm{B} / \mathrm{C} \text { ratio }\end{array}$ & $\begin{array}{l}\text { Gross margin, farm profit, and } \\
\mathrm{B} / \mathrm{C} \text { ratio }\end{array}$ \\
\hline Environmental indicator & - & $\begin{array}{l}\mathrm{CO}_{2} \text { emission in a year from } \\
\text { the diesel pump }\end{array}$ & - \\
\hline
\end{tabular}

\subsubsection{Case 2: Irrigated Farming, Diesel Pump}

In this scenario, irrigation is considered via a diesel pump by pumping water from a deep well. Due to water availability, in this case, farming of only high-value crops (cash crops such as salad, green vegetables) are considered. No cereals of case 1 are produced in this scenario. It is assumed that the farmers can buy these staple cereals with the money they would earn by selling the new cash crops. This case also considers the same land area of 0.15 ha for agricultural production. The following assumptions (Table 1) are considered for the calculations.

\subsubsection{Case 3: Irrigated Farming, Solar Pump}

In this case, crop types and cropping cycle assumptions are similar to those in case 2 above (irrigated farming, diesel pump). The only difference is that the diesel pump is replaced with a solar electric pump for irrigation water supply. To pump the same amount of water as in the diesel pumping case, a $2 \mathrm{~kW}$ solar PV system is considered (which is 
slightly higher than the diesel motor because of the intermittent nature of solar radiation). Solar PV electricity is used exclusively for water pumping for irrigation. The following assumptions (Table 1) are considered for the calculations.

\subsubsection{Case 4: APV for Irrigation and Electricity Supply}

In this case, an APV system is considered in the same reference farm size of $0.15 \mathrm{ha}$. In a land area of 0.15 ha, if all space would be covered with solar panels, a maximum of about $1500 \mathrm{~m}^{2}$ solar panel surface area could be installed. However, literature suggests that only one third of the space could be covered with the APV's solar panels in order to optimize energy and food production together [6]. Also, it is necessary to have a gap between the rows of solar panels in order to allow rainwater to the field in rainy season. Therefore, in this case, only $500 \mathrm{~m}^{2}$ area is assumed as potential solar panels area. Considering the commercially available solar panels in the market, about $10 \mathrm{~m}^{2}$ area will be required to install $1 \mathrm{~kW}$ PV system. Assuming same values for Niger, about $50 \mathrm{~kW}$ solar PV system could be installed in 0.15 ha land. Such a system is much bigger than the one needed only for irrigation water pumping as mentioned earlier (case 3). This means, if the APV system is installed in the reference farm, only a small amount of energy is utilized in pumping, and a big share remains available for other use. This electricity could be supplied to the village by developing necessary distribution network. The alternative would also be to sell it directly to the national grid, where the required regulations allow this.

The crops and farming related assumptions made here are similar to the case 2 and 3 before. Additionally, a crop yield reduction due to solar shading is considered, assuming yield only at $80 \%$ compared to no shading case. On the revenue side, also the electricity sales have been considered. As a financial indicator for the investor, NPV results are presented.

\section{Results and Discussions}

\subsection{Cost Calculation}

The cost distribution of farming in all three cases is presented in Table 2. For easy comparison, the values in Table 2 refer to 1 ha farmland (and not for 0.15 ha case study plot).

In case 1, although the family members work in the field and there are mostly no cash payments involved, a small monetary value (of $91.50 € /$ ha) is assumed for part of the additional human labor that might be needed in different farming activities. For the manual agri-tools, a linearly depreciated annual value of $15.20 € /$ has been used. Not all farmers use inorganic fertilizer or pesticides. However, there is an increasing trend in their use. Only the main crops are considered as the farming produces and only one crop cycle of production is assumed in a year.

In case 2, for the diesel pump of $1.5 \mathrm{~kW}$ (required for 0.15 ha area) with a lifetime of 7 years, the initial cost of $1500 €$ has been considered. Annual depreciation for this machine and agri-tools are considered as fixed costs. When cash crops are planted, the overall need for labor and other farm inputs such as seeds, fertilizer, etc. is higher. Based on the farming costs in similar plots in the suburb of Niamey and considering further assumptions made above for case 1, the individual cost category is quantified. Unlike in case 1, the cost for irrigation needs to be considered here. This is calculated by using diesel consumption in a year and diesel price at a rate of $0.76 € / \mathrm{L}$.

In case 3, the initial cost of the PV pumping system is considered at $5000 €$ (for $2 \mathrm{~kW}$ system needed for 0.15 ha land). Here too, linear depreciation has been applied. Systems lifetime for PV has been considered at 25 years. The annuity value of the fixed costs for pumping was about $1428 € /$ ha and $1333 € /$ ha for diesel and PV irrigated systems respectively. Although the initial cost for a PV irrigation system is higher than a diesel system, the operating costs for the latter are far too high. Annual irrigation operating costs were about $7622 € /$ ha for diesel vs. $667 € /$ ha for PV. Diesel price is the main factor for high value. 
Table 2. Farming cost distribution, cases 1-3 [14,43].

\begin{tabular}{|c|c|c|c|c|c|c|}
\hline & \multicolumn{2}{|c|}{ Case 1, Traditional } & \multicolumn{2}{|c|}{$\begin{array}{c}\text { Case 2, Diesel } \\
\text { Powered Irrigation }\end{array}$} & \multicolumn{2}{|c|}{ Case 3, Solar PV Irrigation } \\
\hline & CFA/ha-Year & (€/ha-Year) & CFA/ha-Year & (€/ha-Year) & CFA/ha-Year & (€/ha-Year) \\
\hline \multicolumn{7}{|l|}{ Variable costs } \\
\hline $\begin{array}{l}\text { Human labor for different } \\
\text { activities }\end{array}$ & 60,000 & 91.50 & $1,000,000$ & 1524.50 & $1,000,000$ & 1524.50 \\
\hline $\begin{array}{l}\text { Machinery use (hand tractor, } \\
\text { plowing) }\end{array}$ & 20,000 & 30.50 & 200,000 & 304.90 & 200,000 & 304.90 \\
\hline Seed & 4000 & 6.10 & 600,000 & 914.70 & 600,000 & 914.70 \\
\hline Fertilizer & 9000 & 13.70 & 700,000 & 1067.10 & 700,000 & 1067.10 \\
\hline Pesticides & 1000 & 1.50 & 100,000 & 152.40 & 100,000 & 152.40 \\
\hline Miscellaneous (packaging, etc.) & 3000 & 4.60 & 200,000 & 304.90 & 200,000 & 304.90 \\
\hline Irrigation use & 0 & 0.00 & $5,000,000$ & $7,622.40$ & 437,307 & 666.67 \\
\hline Subtotal variable costs & 97,000 & 147.90 & $7,800,000$ & $11,891.0$ & $3,237,307$ & 4935.2 \\
\hline \multicolumn{7}{|l|}{ Fixed costs } \\
\hline $\begin{array}{l}\text { Depreciation of hand-made agro } \\
\text { tools (for human labor) }\end{array}$ & 10,000 & 15.20 & 10,000 & 15.20 & 10,000 & 15.20 \\
\hline $\begin{array}{l}\text { Depreciation of diesel or } \\
\text { solar-powered pump }\end{array}$ & 0 & 0 & 937,086 & 1428.57 & $874,613.33$ & 1333.33 \\
\hline Subtotal fixed costs & 10,000 & 15.20 & 947,086 & 1443.80 & 884,613 & 1348.60 \\
\hline Financial costs & 3567 & 5.00 & 291,570 & 444.00 & 137,397 & 209.46 \\
\hline Total costs & 110,567 & 169.00 & $9,038,655$ & $13,779.00$ & $4,259,317$ & 6493.26 \\
\hline
\end{tabular}

\subsection{Revenue Calculation}

For case 1 , the average production quantity and selling prices of these main crops are given in Table 3, as compiled by [43]. There might be few other intercrop vegetables planted parallel in few cases, this has been neglected in the revenue calculation. In all cases, land cost (e.g., rent or purchase) is not considered, because the assumption is that the farmers own small farmland of about 0.15 ha.

Table 3. Production quantity and selling price of main crops in the suburbs of Niamey ([43]).

\begin{tabular}{lcc}
\hline Crop Types & Average Production $(\mathbf{k g} / \mathbf{h a})$ & Average Selling Price $(\boldsymbol{€} / \mathbf{k g})$ \\
\hline Millet & 449 & 0.38 \\
Sorghum & 305 & 0.35 \\
Cowpea & 186 & 0.40 \\
Peanut & 414 & 0.37 \\
\hline
\end{tabular}

In the reference farm, it is assumed that sorghum, millet, and peanut can be planted each in one-third of the land. Cowpea is intercrop with millet and sorghum, this is why only two-third of the land is considered for its production. It should be mentioned that farmers do not earn the revenue in cash, rather they consume the production themselves, and thus there is no need of purchasing these cereals and peanuts from the markets. These crops are given the monetary value $(€ / \mathrm{kg})$ which is applicable in the village (few big farmers sell those produces and their selling price is taken as a reference).

In cases 2 and 3, with irrigation, different salads and green vegetables can be harvested multiple times a year (between 4 and 10 times). To stay on the safe side, only four harvests per year are assumed on average in the calculation. From 0.15 ha land area, about 60 plots $(5 \mathrm{~m} \times 5 \mathrm{~m})$ are typically made. Here, about 20 plots are allocated for salad, and 10 plots 
are allocated for cabbage, tomato, mint, and okra each. The produce will be sold at the market in Kodo or even in Niamey through local traders. In the suburbs of Niamey, there is salad farming, where irrigation water is pumped from the Niger River. There is a common practice of dividing the land area into small plots with an area of about $25 \mathrm{~m}^{2}$. Wholesalers or retailers buy the product there, mostly not based on harvest quantity, but based on the plot itself. Traders buy the plot for a crop cycle and instruct farmers when and how much of the crop is to be harvested. Selling price differs from season to season and from crop to crop. They vary quite a lot even from marketplace to marketplace. Some examples of the price variations around Niamey for 1 plot of land (about $25 \mathrm{~m}^{2}$ ) are given below [43] $(1 €=655.96$ CFA):

- Salad: 3000 to $15000 \mathrm{CFA} /$ plot (3.81 to $22.87 €$ / plot)

- Cabbage: 2500 to $3500 \mathrm{CFA} /$ plot (3.81 to $5.34 € /$ plot)

- Tomato: 3000 to $6000 \mathrm{CFA} /$ plot (4.57 to $9.15 € /$ plot)

- Mint: 4000 to $12000 \mathrm{CFA} /$ plot (6.10 to $18.29 € /$ plot)

- Okra: 3000 to $5000 \mathrm{CFA} /$ plot (4.57 to $7.62 € /$ plot)

To make the calculations representative, market values from Niamey are adapted and a relatively low price is assumed for Dar Es Salam for the revenue calculation considering transport distance to the market, lack of cold storage at the village, etc. An average price assumed for the calculations is given in Table 4.

Table 4. Cash crop types, plots, and average selling price are considered [43].

\begin{tabular}{lccc}
\hline Crop Types & No. of Plots $\left.\mathbf{( 2 5} \mathbf{~ m}^{\mathbf{2}}\right)$ & CFA/Plot & €/Plot \\
\hline Salad & 20 & 5000 & 7.62 \\
Cabbage & 10 & 3000 & 4.57 \\
Tomato & 10 & 3500 & 5.34 \\
Mint & 10 & 6000 & 9.15 \\
Okra & 10 & 3500 & 5.34 \\
\hline
\end{tabular}

\subsection{Financial Indicators for Cases 1-3}

For cases 1-3 mentioned above, the results for gross margin, farm profit, and B/C ratio are presented in Figures $4-6$ respectively.

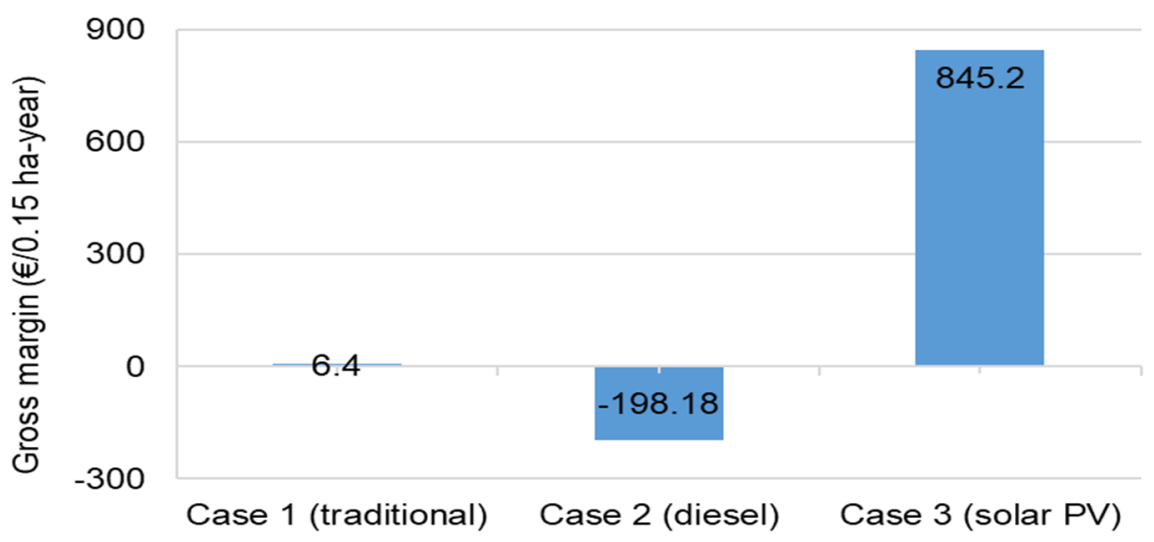

Figure 4. Gross margin for a reference farmer in a year (from 0.15 ha land). 


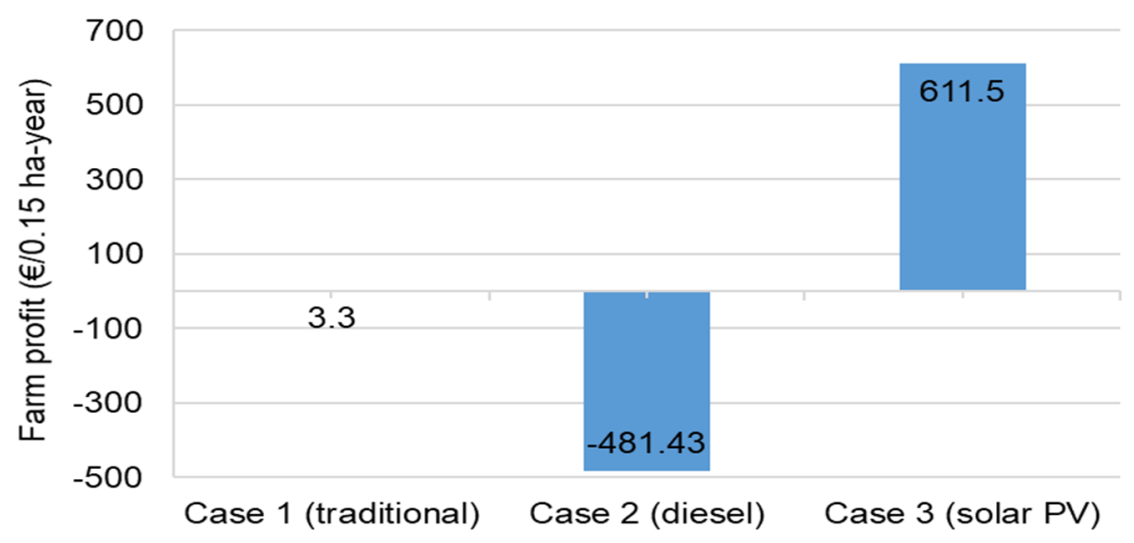

Figure 5. Farm profit for a reference farmer in a year (from 0.15 ha land).

2.00

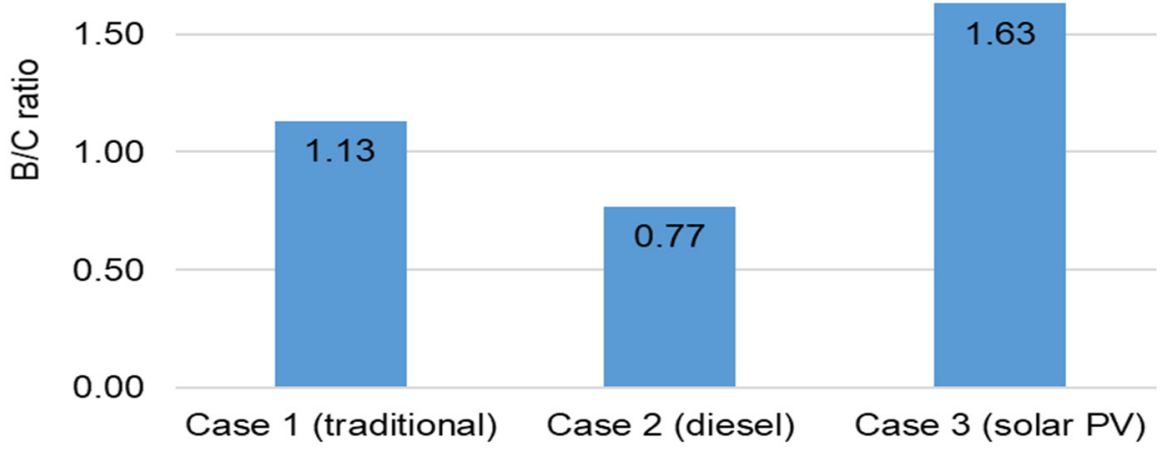

Figure 6. B/C ratio for a reference farmer in a year (from 0.15 ha land).

The economic indicator results are in line with the traditional farming practice in the village, i.e., farming is simply a subsistence agricultural economy. It is almost a net-zero profit activity but is a lifeline for survival.

In case 2 , the results show that the gross margin and farm profit are both negative. The $\mathrm{B} / \mathrm{C}$ ratio is less than one. All three indicators suggest that such a diesel pump-based irrigation system for the reference farm is not economically viable. One of the main reasons is the high cost of diesel. Besides the economic indicators, additional environmental impacts of diesel use for irrigation are calculated in terms of $\mathrm{CO}_{2}$ emissions per year (for $0.15 \mathrm{ha}$ ). To irrigate 0.15 ha of land in a year, about $2700 \mathrm{~m}^{3}$ of water is considered for irrigation and this leads to about $1500 \mathrm{~L}$ diesel consumption. Considering the $\mathrm{CO}_{2}$ emission factor as $2.67 \mathrm{kgCO}_{2} / \mathrm{L}$ for diesel motors [44], the total annual $\mathrm{CO}_{2}$ emission is calculated at about $4005 \mathrm{~kg} /$ year.

Among the discussed three cases, solar-powered irrigation systems perform the best. All indicators are positive. Due to relatively small PV system size and longer lifetime, the annual cost related to irrigation is much lower compared to case 2, with diesel.

The levelized cost of water (LCOW) has been also calculated by dividing the annuity value of total irrigation system cost divided by total annual irrigation water consumed. The obtained values are $0.11 € / \mathrm{m}^{3}$ vs. $0.50 € / \mathrm{m}^{3}$ for solar vs. diesel case respectively.

\subsection{Case of Agrivoltaic (APV)}

APV specific assumptions used for calculation in the model are given in Table 5. 
Table 5. PV specific parameters.

\begin{tabular}{lcc}
\hline Description & Value & Unit \\
\hline Radiation at standard test condition, $\mathrm{I}_{\text {stc }}$ & 1 & $\mathrm{~kW} / \mathrm{m}^{2}$ \\
Solar yield degradation rate, $\mathrm{d}_{\mathrm{g}}$ & 0.5 & $\mathrm{k}$ \\
Peak power of PV system, $\mathrm{P}_{\mathrm{p}}$ & 50 & $\mathrm{~kW}$ \\
Performance ratio, Q & 60 & $\mathrm{~kW}$ \\
PV size for irrigation pump, $\mathrm{P}_{\text {irrigation }}$ & 2 & $\%$ \\
Discount rate in Niger, $\mathrm{d}$ & $6[45]$ & $€ / \mathrm{kWh}$ \\
Grid tariff for electricity selling, $\mathrm{P}_{\mathrm{el}}$ & 0.10 & numbers \\
Number of households & 400 & $\mathrm{kWh} /$ year \\
Annual electricity demand per household & 300 & $€ / \mathrm{kW}$ \\
Solar PV system cost & 1200 & $€ / \mathrm{kW}$ \\
APV structure costs & 50 & $\%$ of initial cost \\
Repair, operation, maintenance costs & 2 & $\mathrm{kWh} / \mathrm{m}^{2}$-year \\
Solar radiation data on an inclined & 2244 (Meteonorm V. 8) & \\
surface (tilt at $15^{\circ}$ ) & &
\end{tabular}

The amount of electricity generation in the year will be about 67.32 MWh. Due to the considered degradation rate, the yield will be smaller in each following year, with a value for the final year at only 59.69 MWh. The irrigation water demand (for the same reference farm size) will be constant at $2693 \mathrm{kWh} /$ year throughout these years. This leads to huge surplus electricity that needs to be used e.g., connection to central grid or its use in village electrification.

As the solar system size that can be installed in such a large land area is bigger compared to the one needed to pump irrigation water as in case 3 above, different scenarios are considered in this case. Based on the total cost and total revenue of the whole APV system, the economic indicators are calculated and the results are presented in the following two scenarios.

\subsubsection{Scenario 1, Benefits to Investor}

In this scenario, the APV system is installed by an investor. Farmer has to pay the electricity tariff for water pumping electricity needs. Practically, the farmer could switch from traditional cereals farming to cash crops farming and enjoy the higher revenue similar to cases 2 and 3 before.

For an investor, the total costs include the APV system investment cost as well as annual repair and maintenance costs. The revenue includes electricity sales to the grid and farmers. This village is not connected to the grid yet. Therefore, at the moment it is a hypothetical scenario that the mentioned revenue would be collected. However, if the villagers are supplied with the electricity after building the required local supply infrastructures, this revenue can be easily collected. The electricity selling rate considered (i.e., $0.10 € / \mathrm{kWh}$ ) is slightly below the current grid electricity tariff in Niger (about $0.12 € / \mathrm{kWh}$ for consumers with demand in the range of 150-300 kWh in a year).

The project lifetime is relatively long, i.e., 25 years. Nominal annual revenue from the electricity sale is almost similar over the years (only affected by a slight decrease in yield, due to degradation rate of solar PV electricity yield caused by solar glass scratches, etc.). As the economic indicator for the investor, NPV is calculated by discounting the annual net cash flows. The calculated NPV is about $7779 €$ for the investor. With irrigation, the farmer will have higher farm profit (due to higher revenue as reported in case 3 before). This will be a win-win scenario for both investors and farmers.

\subsubsection{Scenario 2, Overall Benefits (Combined of Both Farmer and Investor)}

This scenario is the same as scenario 1, except for revenue calculations. In this case, the farmer's income from cash crops farming as well as investor's income from electricity sales are considered in the revenue calculation (discounted annual farm profit plus the investor's NPV, for the same accounting period of 25 years). 
One further aspect of the negative shading effect on agricultural yield has also been considered. Crop production in this shading case is assumed at about $80 \%$ of the normal production. This reduction has an impact on the farmer's revenue. As expected, the combined NPV values are higher than in the individual case, even after considering the mentioned shading effect. The combined NPV values are compared in Figure 7.

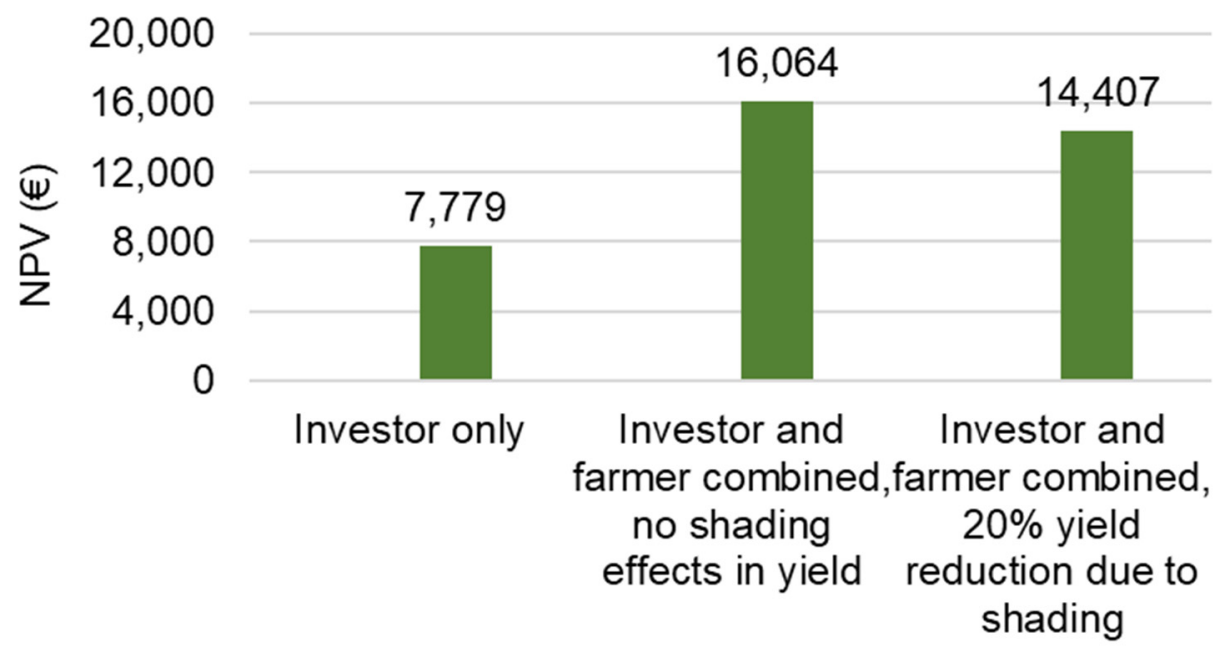

Figure 7. NPVs under different scenarios.

Overall, this can be interpreted that the APV system is economically profitable under the assumptions made in this study, both for farmers and PV investors.

For scenario 2 above, the LER can be calculated by using Equation (1). The obtained LER values are 1.33 and 1.13 for the case without and with yield reduction due to APV shading, respectively. The LER results show that the double use of land is more effective. Furthermore, when the APV system is installed, people will benefit from access to electricity, even if they will need to pay for the electricity. For the village's about 400 households, assuming annual electricity demand of up to $323 \mathrm{kWh} /$ year (typical value in rural areas of developing countries lies about $300 \mathrm{kWh}$ ), only about 2 such APV systems would be able to supply the electricity needs of the village.

\subsection{Sensitivity Analysis}

As the study has many assumptions, it is necessary to analyze the sensitivity of some crucial parameters with regard to the financial indicators. For the following selected parameters, such analysis has been made.

\subsubsection{Diesel Based Irrigation System, Case for Farmers}

The price fluctuation of the cash crop can be much higher than currently expected. Therefore, a sensitivity analysis is carried out to observe the influence of selling price changes on the $\mathrm{B} / \mathrm{C}$ ratio in (Figure 8). The results show that to reach the farming system $\mathrm{B} / \mathrm{C}$ ratio to 1 , the average selling price for all crops shall increase at least by $30 \%$, which is currently not realistic. 


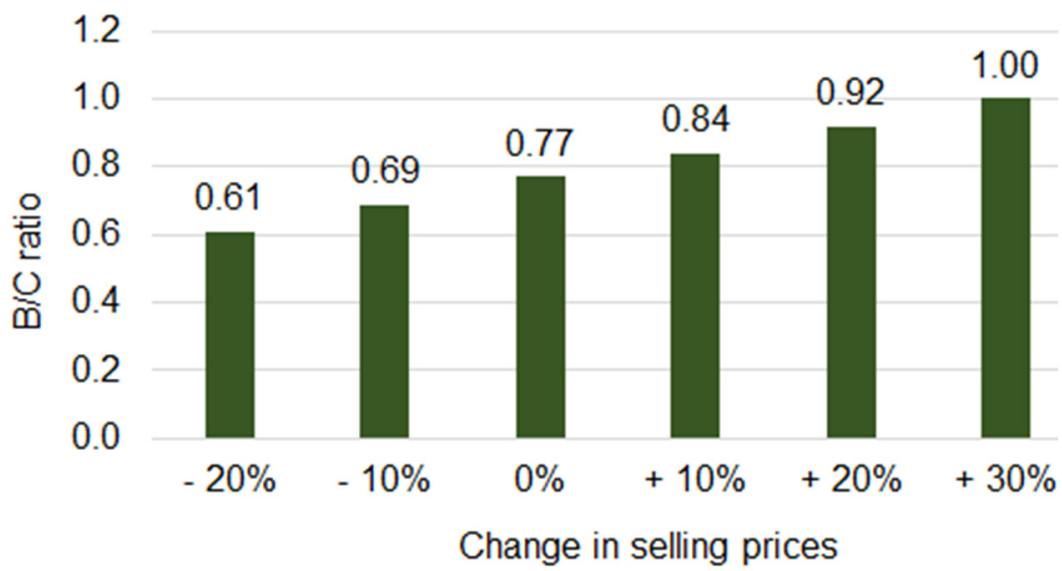

Figure 8. Effect of crop selling price changes to B/C ratio, case diesel.

The diesel price might vary in the market from the currently taken price of $0.76 € / \mathrm{L}$. Cost for diesel has a significant share in total cost, therefore the sensitivity analysis is carried out to observe the impact of diesel price variations on the $\mathrm{B} / \mathrm{C}$ ratio. Results are presented in Figure 9. It can be interpreted that the diesel price shall drop below $40 \%$ from its current level to be the farming system at cost breakeven point. This scenario is also not realistic looking at the overall trends of rising petroleum prices in recent years.

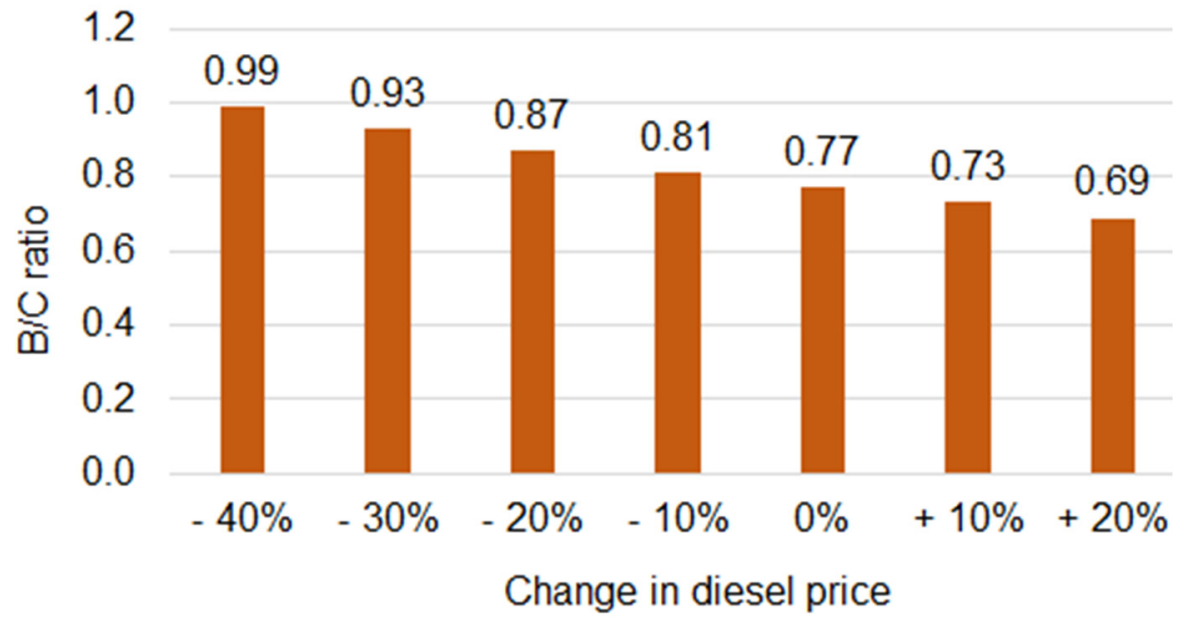

Figure 9. Effect of crop selling price changes to B/C ratio, case diesel.

\subsubsection{APV System, Case for Investors}

The calculated value of LCOE is at $9.11 € \mathrm{ct} / \mathrm{kWh}$ (with the energy yield discounted to its present value at a baseline discount rate of $6 \%$ ). When the lesser discount rates e.g., $2 \%$ or $4 \%$, and higher performance ratio (e.g., $70 \%$ or $80 \%$ ), are considered, corresponding LCOE values will be lower, as shown in Figure 10.

On the revenue side, the most important parameter is the electricity selling tariff. Therefore, its influence on the NPV is calculated and the results are presented in Figure 11. If the selling tariff goes below $0.0911 € / \mathrm{kWh}$, the NPV will start to get negative. Therefore, this is the breakeven selling tariff. 


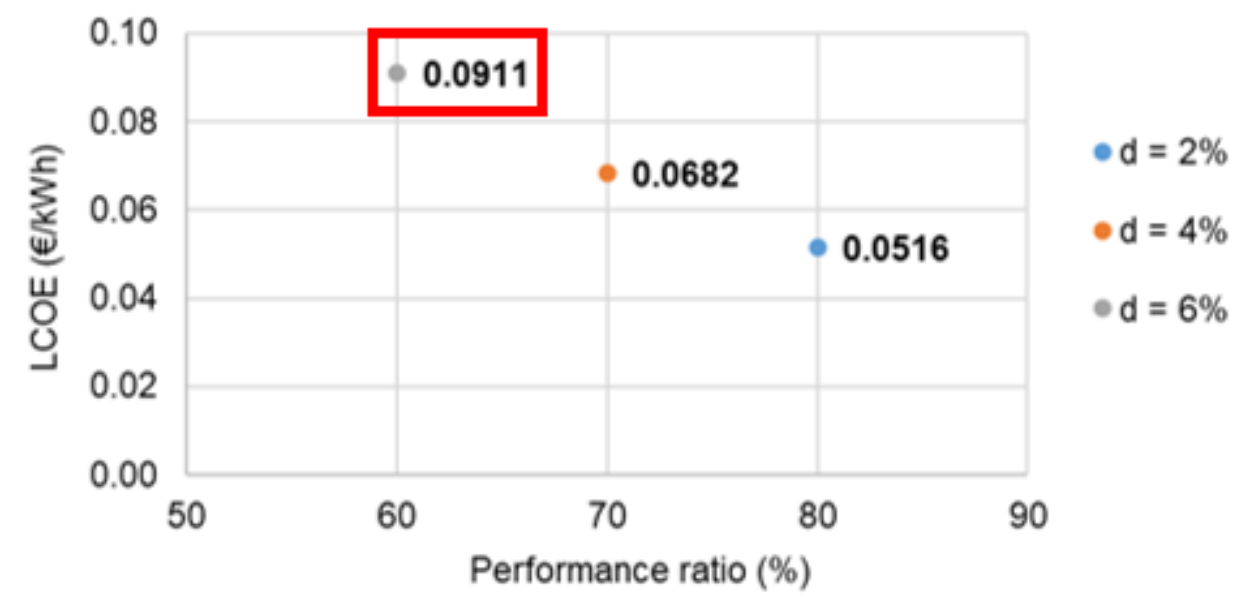

Figure 10. LCOE values under different discount rates and performance ratios.

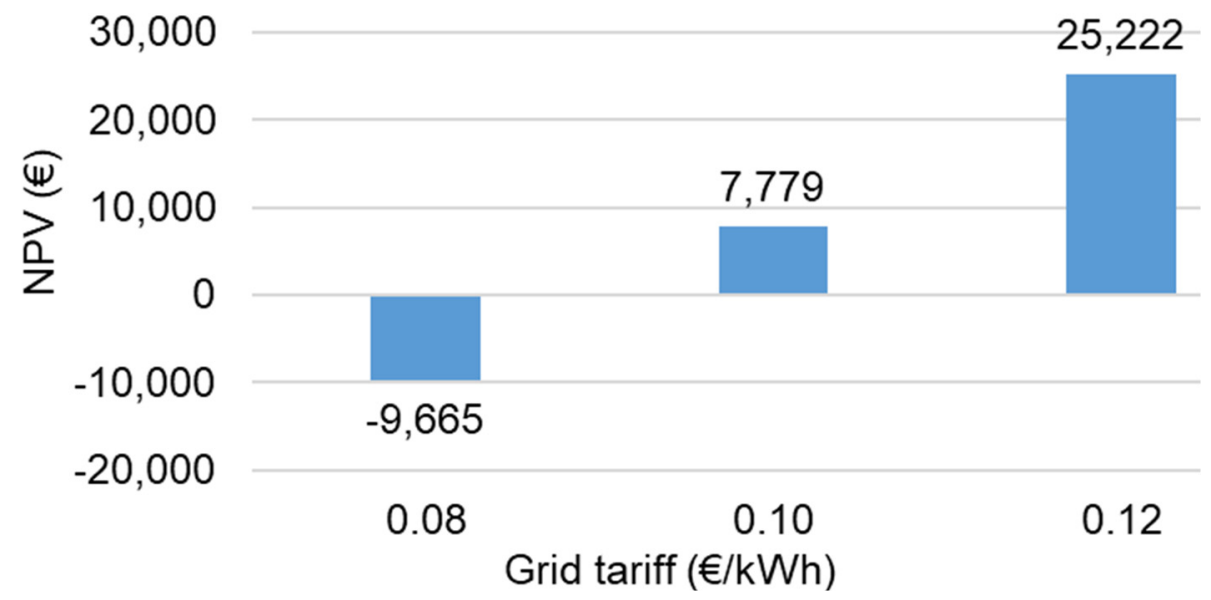

Figure 11. Effect of the electricity selling price to NPV, a case for investors.

On the cost side, the PV system cost is the most important parameter that determines the total system cost. The influence of change in PV system costs on the NPV is shown in Figure 12. It is expected that the solar systems will be cheaper in the coming years (if they follow the trend of the recent past). In that case, the APV system seems further promising.

In this case, the benefits to the farmer will not change much in comparison to the results presented above in Section 4.4 because this does not lead to significant extra cost for irrigation electricity (only a very small fraction of the APV electricity goes for irrigation of 0.15 ha land considered).

\subsubsection{APV System, Both Cases (Combined Benefits and Shading Effect)}

The results presented above in Figure 8 are based on the assumed value of a discount rate of $6 \%$ [45]. For APV projects with a long lifetime, the selection of the correct discount rate is important. A high discount rate leads to a smaller value of NPV as well as a higher value of LCOE. Figure 13 shows the calculated values of NPVs under the different scenarios for discount rates. 


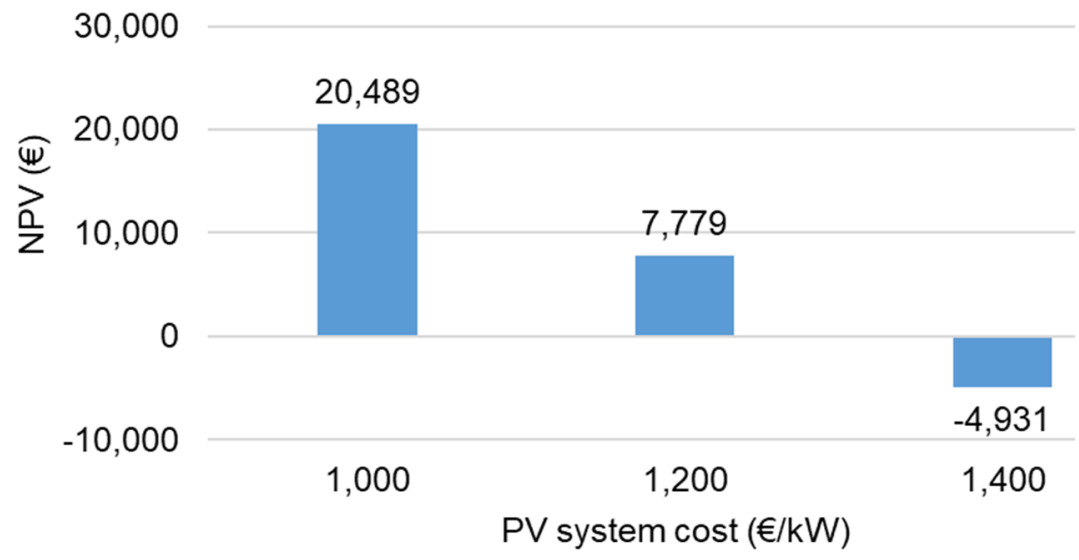

Figure 12. Effect of PV system cost to NPV, a case for investors.

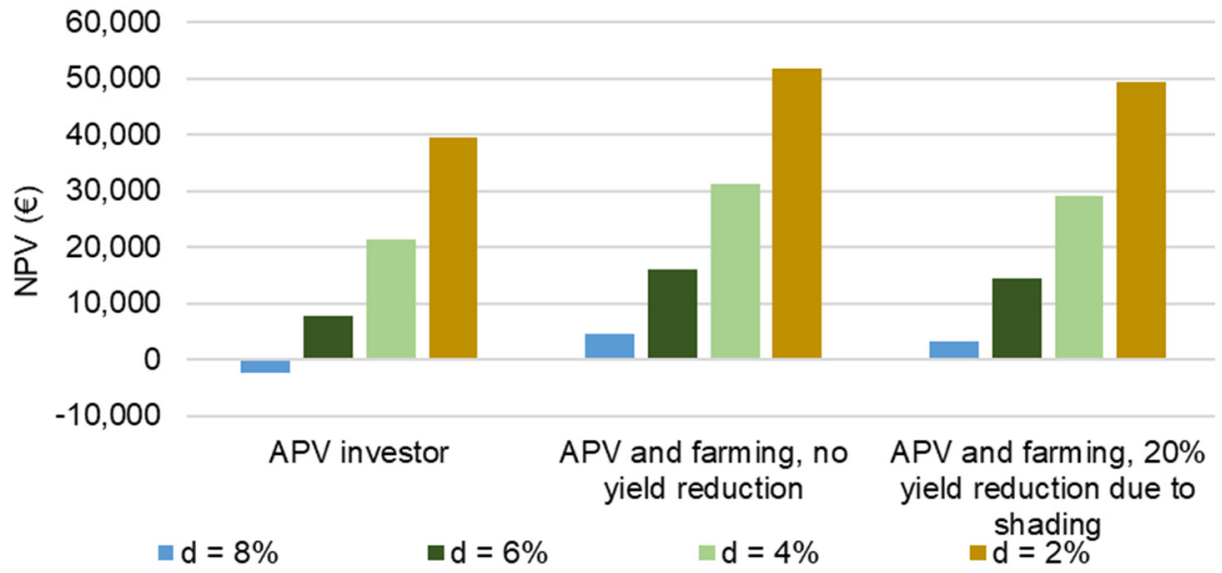

Figure 13. NPVs under different scenarios with varying discount rates.

Besides these direct monetary benefits to the investor, there are many indirect benefits of the APV. It could contribute to the GHG emission reduction year by year by avoiding the use of possible diesel-powered irrigation. In many regions of the world, diesel-powered irrigation is a common practice today. On top of that, when the electricity from APV is used to gradually replace the existing grid electricity in Niger, which is dominated by non-renewable energy, a significant contribution to the GHG emission reduction can be considered.

As expected, the LER results showed that the double use of land is more effective. Furthermore, when the APV system is installed, people will benefit from access to electricity, even if they will need to pay for the electricity (considered in the above analysis $0.10 € / \mathrm{kWh}$ ). Considering the village's household at about 400, and annual electricity demand of $323 \mathrm{kWh}$ /year (typical value in rural areas of developing countries lies about $300 \mathrm{kWh}$, including Nepal), only about 2 such APV plants would be able to supply the lighting electricity needs of the village.

Another positive aspect of such APV would be the access to clean and sufficient drinking water to the villagers, which is currently a big problem as described in the previous chapter. Therefore, such an APV system's surplus electricity (after irrigation) could be used for additional water pumping for such water use purposes.

\section{Conclusions}

Based on the results described above, it can be concluded that the APV is a promising option in the village of Dar Es Salam. Implementation of APV could significantly increase 
the economic activities in the village, mainly in the field of small agricultural enterprises. In all four scenarios considered under APV, the results are positive and such a system seems to be an appropriate option to supply food and energy in the village. In a broad estimate, only two such APV systems would be able to supply the village's 400 households with electricity (about $323 \mathrm{kWh}$ /year). APV systems are win-win options for both farmers and investors.

The analysis above is based on several stated assumptions. Therefore, the presented results are only valid, if these assumptions come true during the implementation of the real project. To validate the results presented in this study, it is necessary to install an APV system and perform the experimental analysis on-site. Based on these results, different business cases can be developed and practical business models can be developed for different interest groups: farmers, investors, and traders (in agri-value-chain). This experimental work shall be the next step in this field.

Author Contributions: Conceptualization, S.N.B., R.B., and R.A.; methodology, S.N.B., W.K., and H.S.; investigation, S.N.B.; writing —original draft preparation, S.N.B.; writing-review and editing, S.N.B., W.K., H.S., and R.B.; supervision, S.S. and R.A.; revision, S.N.B. and R.B.; project administration, R.B.; funding acquisition, R.B. All authors have read and agreed to the published version of the manuscript.

Funding: This research was funded by the Federal Ministry of Education and Research (BMBF) in Germany through its Project Management Agency Jülich (PtJ) under the framework of the RETODOSSO project, grant number 03SF0598A. The APC was funded by the same.

Institutional Review Board Statement: Not applicable.

Informed Consent Statement: Not applicable.

Data Availability Statement: Not applicable.

Acknowledgments: Thanks are also due to Adamou Hassane and his team at the University of Niamey who coordinated the field interview at the reference farm by using the questionnaire developed by the first author of this paper.

Conflicts of Interest: The authors declare no conflict of interest.

\section{References}

1. Fraunhofer ISE. Harvesting the Sun for Power and Produce-Agrophotovoltaics Increases the Land Use Efficiency by Over 60 Percent; Fraunhofer ISE: Freiburg, Germany, 2017.

2. Goetzberger, A.; Zastrow, A. On the Coexistence of Solar-Energy Conversion and Plant Cultivation. Int. J. Sol. Energy 1982, 1, 55-69. [CrossRef]

3. Brohm, R.; Khanh, N.Q. Dual Use Approaches for Solar Energy and Food Production-International Experience and Potentials for Vietnam; Green Innovation and Development Centre (GreenID): Hanoi, Vietnam, 2018.

4. Mead, R.; Willey, R.W. The Concept of a 'Land Equivalent Ratio' and Advantages in Yields from Intercropping. Exp. Agric. 1980, 16, 217-228. [CrossRef]

5. Dinesh, H.; Pearce, J.M. The potential of agrivoltaic systems. Renew. Sustain. Energy Rev. 2016, 54, 299-308. [CrossRef]

6. Weselek, A.; Ehmann, A.; Zikeli, S.; Lewandowski, I.; Schindele, S.; Högy, P. Agrophotovoltaic systems: Applications, challenges, and opportunities. A review. Agron. Sustain. Dev. 2019, 39, 35. [CrossRef]

7. Hernandez, R.R.; Armstrong, A.; Burney, J.; Ryan, G.; Moore-O'Leary, K.; Diédhiou, I.; Grodsky, S.M.; Saul-Gershenz, L.; Davis, R.; Macknick, J.; et al. Techno-ecological synergies of solar energy for global sustainability. Nat. Sustain. 2019, 2, 560-568. [CrossRef]

8. Barron-Gafford, G.A.; Pavao-Zuckerman, M.A.; Minor, R.L.; Sutter, L.F.; Barnett-Moreno, I.; Blackett, D.T.; Thompson, M.; Dimond, K.; Gerlak, A.K.; Nabhan, G.P.; et al. Agrivoltaics provide mutual benefits across the food-energy-water nexus in drylands. Nat. Sustain. 2019, 2, 848-855. [CrossRef]

9. Majumdar, D.; Pasqualetti, M.J. Dual use of agricultural land: Introducing 'agrivoltaics' in Phoenix Metropolitan Statistical Area, USA. Landsc. Urban Plan 2018, 170, 150-168. [CrossRef]

10. Dupraz, C.; Marrou, H.; Talbot, G.; Dufour, L.; Nogier, A.; Ferard, Y. Combining solar photovoltaic panels and food crops for optimising land use: Towards new agrivoltaic schemes. Renew. Energy 2011, 36, 2725-2732. [CrossRef]

11. Marrou, H.; Guilioni, L.; Dufour, L.; Dupraz, C.; Wery, J. Microclimate under agrivoltaic systems: Is crop growth rate affected in the partial shade of solar panels? Agric. For. Meteorol. 2013, 177, 117-132. [CrossRef] 
12. Beck, M.; Bopp, G.; Goetzberger, A.; Obergfell, T.; Reise, C.; Schindele, S. Combining PV and food crops to agrophotovoltaicOptimization of orientation and harvest. In Proceedings of the 27th European Photovoltaic Solar Energy Conference and Exhibition, EU PVSEC, Frankfurt, Germany, 24-28 September 2012.

13. Sekiyama, T.; Nagashima, A. Solar Sharing for Both Food and Clean Energy Production: Performance of Agrivoltaic Systems for Corn, A Typical Shade-Intolerant Crop. Environments 2019, 6, 65. [CrossRef]

14. Neupane Bhandari, S. Feasibility Analysis of Agrivoltaic Systems: Case Study of Food Energy Nexus in Niger; TH Köln-University of Applied Sciences: Cologne, Germany, 2020.

15. Vyas, K. Solar Farming with Agricultural Land. Acta Sci. Agric. 2019, 3, 23-25. [CrossRef]

16. Santra, P.; Singh, R.K.; Meena, H.M.; Kumawat, R.N.; Mishra, D.; Jain, D.; Yadav, O.P. Agrivoltaic system: Crop production and photovoltaic-based electricity generation from a single land unit. Indian Farming 2018, 68, 20-23.

17. Malu, P.R.; Sharma, U.S.; Pearce, J.M. Agrivoltaic potential on grape farms in India. Sustain. Energy Technol. Assess. 2017, 23, 104-110. [CrossRef]

18. Valle, B.; Simonneau, T.; Sourd, F.; Pechier, P.; Hamard, P.; Frisson, T.; Ryckewaert, M.; Christophe, A. Increasing the total productivity of a land by combining mobile photovoltaic panels and food crops. Appl. Energy 2017, 206, 1495-1507. [CrossRef]

19. Ravi, S.; Macknick, J.; Lobell, D.; Field, C.; Ganesan, K.; Jain, R.; Elchinger, M.; Stoltenberg, B. Colocation opportunities for large solar infrastructures and agriculture in drylands. Appl. Energy 2016, 165, 383-392. [CrossRef]

20. Amaducci, S.; Yin, X.; Colauzzi, M. Agrivoltaic systems to optimise land use for electric energy production. Appl. Energy 2018, 220, 545-561. [CrossRef]

21. Harinarayana, T.; Vasavi, K. Solar Energy Generation Using Agriculture Cultivated Lands. Smart Grid Renew. Energy 2014, 5, 31-42. [CrossRef]

22. Movellan, J. Japan Next-Generation Farmers Cultivate Crops and Solar Energy. 2013. Available online: https://www. renewableenergyworld.com/2013/10/10/japan-next-generation-farmers-cultivate-agriculture-and-solar-energy/ (accessed on 17 October 2020).

23. Moreda, G.P.; Muñoz-García, M.A.; Alonso-García, M.C.; Hernández-Callejo, L. Techno-Economic Viability of Agro-Photovoltaic Irrigated Arable Lands in the EU-Med Region: A Case-Study in Southwestern Spain. Agronomy 2021, 11, 593. [CrossRef]

24. Ibrik, I. Micro-Grid Solar Photovoltaic Systems for Rural Development and Sustainable Agriculture in Palestine. Agronomy 2020, 10, 1474. [CrossRef]

25. Pascaris, A.S.; Schelly, C.; Pearce, J.M. A First Investigation of Agriculture Sector Perspectives on the Opportunities and Barriers for Agrivoltaics. Agronomy 2020, 10, 1885. [CrossRef]

26. Hassanien, R.H.E.; Li, M.; Dong Lin, W. Advanced applications of solar energy in agricultural greenhouses. Renew. Sustain. Energy Rev. 2016, 54, 989-1001. [CrossRef]

27. NREL. Benefits of Agrivoltaics across the Food-Energy-Water Nexus. 2019. Available online: https://www.nrel.gov/news/ program/2019/benefits-of-agrivoltaics-across-the-food-energy-water-nexus.html (accessed on 12 July 2020).

28. Njita, N.F. Increasing Agricultural Land Use Efficiency and Generating Electricity Using Solar Modules; Lappeenranta University of Technology: Lappeenranta, Finland, 2018.

29. Patel, B.; Gami, B.; Baria, V.; Patel, A.; Patel, P. Co-Generation of Solar Electricity and Agriculture Produce by Photovoltaic and Photosynthesis-Dual Model by Abellon, India. J. Sol. Energy Eng. 2019, 141, 031014. [CrossRef]

30. EERE. Farmer's Guide to Going Solar. 2020. Available online: https:/ /www.energy.gov/ eere/solar/farmers-guide-going-solar (accessed on 21 September 2020).

31. Ketzer, D.; Schlyter, P.; Weinberger, N.; Rösch, C. Driving and restraining forces for the implementation of the Agrophotovoltaics system technology-A system dynamics analysis. J. Environ. Manag. 2020, 270, 110864. [CrossRef] [PubMed]

32. CIA. The World Factbook-Niger. 2020. Available online: https://www.cia.gov/library/publications/the-world-factbook/geos/ ng.html (accessed on 18 September 2020).

33. Knoema. Niger-Total Population. 2020. Available online: https://knoema.com/atlas/Niger/Population (accessed on 10 September 2020).

34. FAO. Aquastat: Country Statistics 2017-Niger. 2021. Available online: http://www.fao.org/aquastat/statistics/query/index. html?lang=en (accessed on 23 June 2021).

35. ICRISAT. Niger: Facts and Figures. 2020. Available online: http:/ / exploreit.icrisat.org/profile/Niger/334 (accessed on 26 August 2020).

36. USAID. Off-Grid Solar Market Assessment; United States Agency for International Development (USAID): 2019. Available online: https:/ / www.usaid.gov/sites/default/files / documents /1860/PAOP-Niger-MarketAssessment-Final_508.pdf (accessed on 14 August 2020).

37. Andres, L.; Lebailly, P. Peri-urban Agriculture: The Case of Market Gardening in Niamey, Niger. Afr. Rev. Econ. Financ. 2011, 3 , 69-85.

38. Bhandari, R.; Sessa, V.; Adamou, R. Rural electrification in Africa-A willingness to pay assessment in Niger. Renew. Energy 2020, 161, 20-29. [CrossRef]

39. Tilahun, F.B.; Bhandari, R.; Mamo, M. Supply optimization based on society's cost of electricity and a calibrated demand model for future renewable energy transition in Niger. Energy Sustain. Soc. 2019, 9, 31. [CrossRef] 
40. Bhandari, R.; Arce, B.E.; Sessa, V.; Adamou, R. Sustainability Assessment of Electricity Generation in Niger Using a Weighted Multi-criteria Decision Approach. Sustainability 2021, 13, 385. [CrossRef]

41. Kahan, D. Economics for Market Oriented Farming; Food and Agriculture Organization (FAO) of the United Nations: Rome, Italy, 2008.

42. World Bank. Solar Pumping - The Basics; The World Bank (WB): Washington, DC, USA, 2018.

43. ITT. Final Report on the Project RARSUS; TH Köln-University of Applied Sciences: Cologne, Germany, 2020.

44. ECG. Feasibility Assessment for the Replacement of Diesel Water Pumps with Solar Water Pumps; Emcon Consulting Group (ECG): Windhoek, Namibia, 2006.

45. World Bank. International Development Association Project Paper on a Proposed Additional Credit and Grant to the Republic of Niger for the Electricity Access Expansion Project. The World Bank: 2018. Available online: https://documents1.worldbank.org/curated/en/ 630161534524243997/pdf/NIGER-ELECTRICITY-PAD-08142018.pdf (accessed on 23 November 2020). 